
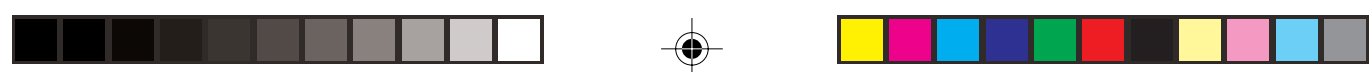

\title{
Reviews
}

ANDREA KING is an Auckland freelance writer and a graduate of Temple University's School of Journalism, Philadelphia.

\section{Holding the US Fourth Estate to account on Iraq}

Feet to the Fire: The Media after 9/11, edited by Kristina Borjesson. New York: Prometheus Books, 2005. 575 pp ISBN: 1591023432 (cloth).

The performance of the American press leading up to the second Gulf War or the invasion of Iraq was ... just pathetic. It was the worst it's been since before Vietnam. The American press swallowed and regurgitated and amplified just about every lie the Bush administration put forward, starting with a press conference on 7 September 2002, featuring Tony Blair and George Bush, where they spoke about a new report from the International Atomic Energy Agency that supposedly said that Saddam was six months away from building a nu-

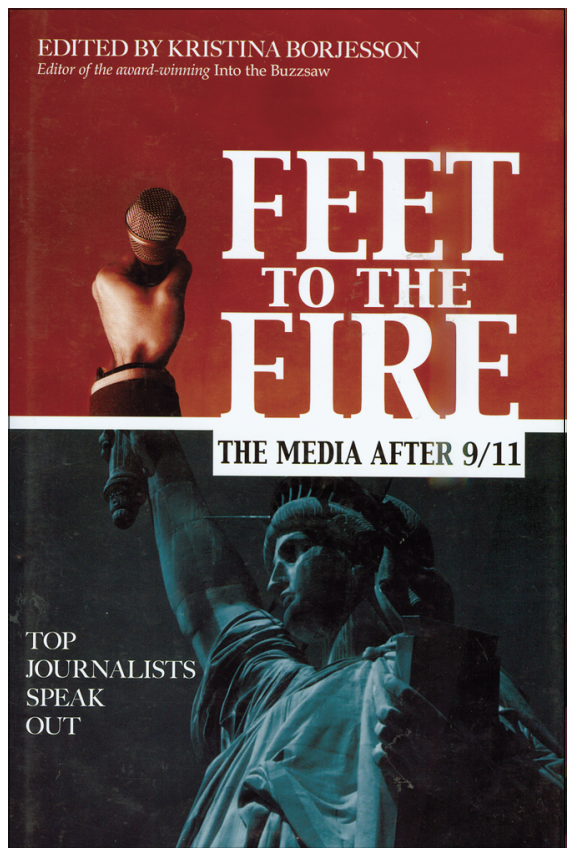

clear weapon. There was no new report. Few in the press pointed it out immediately. This is major news; 'President cites nonexistent report menacing nuclear holocaust,' and practically no one reports it. (John MacArthur, p. 93)

TT IS a truism that one should not shoot the messenger who brings bad news. But what about the messenger who ignores or discards bad news? In the 1970s, the role of investigative reporting in the Vietnam 
war, the exposure of the Watergate scandal and the subsequent downfall of President Richard Nixon elevated journalists to folk-hero status in the US. The resulting image of journalists-whip-smart, fearless and always one step ahead of the people and events they are covering-persisted through the end of the 20th century.

But this image has taken a battering since the American invasion of Iraq in 2003. Journalists are widely perceived to have abdicated their watchdog role during the run-up to the invasion, accepting the tenuous rationale offered by the Bush administration.

Investigative reporter Kristina Borjesson is an award-winning independent producer and writer for both commercial and nonprofit television and radio in the US. In recent years she has turned to investigating her own industry, examining contemporary journalism from a participantobserver perspective. Her 2002 book Into the Buzzsaw was a collection of essays on censorship by prominent American journalists.

In Feet to the Fire, she interviews key journalism figures about the press's collective failure to significantly challenge the invasion of Afghanistan. The result is a multi-perspective documentary account of the state of political journalism in George W. Bush's America.

Television producer Tom Yellin told Borjesson: 'The complexity and diversity of American journalism is its greatest strength' (p. 66). The lineup of interviewees in Feet to the Fire illustrates this diversity: a broad cross-section of journalists, print and broadcast, independent and affiliated, from television network and publishing executives down to ground-level war correspondents.

The result is an equally diverse assortment of responses to Borjesson's central questions: Why did the US really go to war in Iraq, and why was the press so slow to question the Bush administration's rationale for the invasion?

Feet to the Fire reads like a whodunit as each voice weighs in with an additional piece of the puzzle. The collection is structured from the top down, beginning with high-level and high-profile media figures, moving on to investigative reporters covering the government beat and Middle East experts, and ending with the Middle East correspondents. It is bookended by an opening interview with veteran anchorman Ted Koppel, indisputably the most prominent person in the book, and the final one with Gen-X war correspondent Tom Lasseter.

Collectively, the interviews 


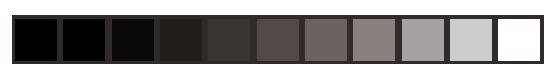

amount to a chorus of disapproval as journalists acknowledge their own shortcomings and those of the industry. War correspondent Chris Hedges, who covered the invasion for the New York Times, is unequivocal:

As somebody who was on the investigative unit after $9 / 11$ and covered al-Qaeda, as someone who spent seven years of my life in the Middle East and who speaks Arabic, I found the coverage shameful and appalling. I'm surprised that in retrospect anyone would defend it. During that time, there was this kind of blind euphoria and patriotic zeal and fear, which often happens in wartime. Remember, the attacks happened in New York, and that affected many of the media organisations based there. That led to a really unquestioning attitude on the part of the press toward the information that was being handed to it by ideologues who we now know cooked the information. (p. 518)

But Tom Yellin cautions against viewing the press as monolithic:

... [I]t's important to make distinctions among the different reporters and different organisations. ... [S]ome excellent reporting was done before, during and after the combat phase of the war, and some of that reporting continues to this day. One of the things that was heavily reported before the war was the deep disagreements that existed within the military about the logic for the war ... So it's not as though the press as a group marched uniformly behind President Bush and the civilians in his administration who were arguing for the war. (p. 53-54)

Borjesson anticipated that the political climate resulting from the $9 / 11$ terrorist attacks would be cited as a major factor, and her subjects generally agree that it cannot be underestimated. Asked bluntly, 'Why do you think the press laid down on the job?' Helen Thomas, longtime White House correspondent for Associated Press, responds just as bluntly:

Fear. The fear card was very important. Everybody felt the tension of $9 /$ $11,9 / 11,9 / 11$, and then going into a war you don't want to rock any boats. ... Nobody wants to be considered unpatriotic or un-American in these crises. (p. 127)

Another factor cited by a number of interviewees is the Bush administration's conscious and deliberate manipulation of the press in order to conceal their pre-existing agenda of invading Iraq behind fictional accounts of weapons stockpiles and terrorist connections. Deborah Amos, Middle East correspondent for Na- 


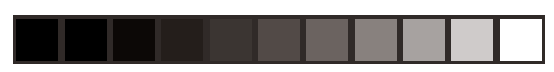

tional Public Radio, concedes:

At the time I probably didn't question [disparities about Iraqi weapons]. Looking back, we didn't know then what we know now about this administration. These guys are master spinners.

Former Wall Street Journal reporter Ron Suskind, author of an acclaimed insider's-view book about the Bush White House, is more explicit:

The press was up against a strategic model to keep not just them but the American public and their representatives in Congress from seeing clearly the true reasons and motivations that ultimately drove us to war. (p. 166)

Another significant factor cited by a number of interviewees is the toocozy symbiosis between mainstream political journalists and the people they cover. John MacArthur, the independent president/publisher of Harper's Magazine, offers a deceptively droll account of this collaboration:

The reporters and the editors in Washington flatter themselves that they are part of the constitutional apparatus and that gives them a special responsibility to be polite to politicians. That's one theory. My theory

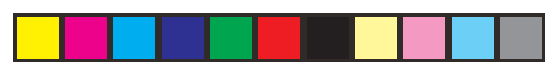

is more along the lines of the social: that nobody likes to be isolated socially. Everybody wants to be at Versailles. Washington is Versailles. They want to be close to le roi soleil [the sun king], they want to be part of the power structure, and if taking the official leak from the official source gets you credit within your news organisation, getting close to Cheney, getting close to Rumsfeld, getting their story across to the American people - if that brings you credit and more invitations and more promotions, it's a great way to live. If you go contrary to that, you wind up back in Cleveland. (pp. 98-99)

The risk of challenging this gentlemen's agreement is vividly illustrated by Helen Thomas, who was frozen out by the Bush White House after a distinguished career covering nine presidents:

There had been a horrifying suicide bombing and Fleischer (then-press secretary Ari Fleischer) came out and said 'The president deplores this terrible act.' So I said to him, 'Ari, this morning you said that the president deplored the suicide bombing. Why does he want to bomb and kill thousands of Iraqis, including women and children?' ...

He said: 'They have a dictator.' And I said, 'But why does the president want to bomb them.' And Fleischer responded, 'They have no control

186 PACIFIC JOURNALISM REVIEW 12 (2) 2006 


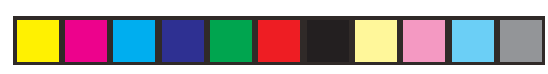

over their lives, they have no say in their government.' And I said, 'And neither do we.' From then on, it was war. (pp. 126-127)

Feet to the Fire also contains a thorough, even exhaustive, account of coverage of the invasion and the ongoing war.

The final section, 'The War Correspondents', offers some of the book's most riveting reading. But the zoom-lens approach of these chapters diverges somewhat from the book's original broad focus, and the experiences of these foot soldiers of journalism could easily form the basis for another book.

In fact, the interviews reveal many more stories waiting to be told, and the meticulous references offer plenty of material for further reading or-even better-further investigative writing.

The book will be of particular interest to journalists and journalism students, but it should be read by anyone seeking the truth about the standoff between Bush's America and the Islamic Middle East. Ultimately Borjesson's collection shows the messenger counting its wounds and undergoing the painful process of regaining its balance and objectivity, revealing both the limits and the promise of the role of contemporary journalism in current affairs, and why in this, as in all crises, we need to hold the Fourth Estate to account.

\section{Reference:}

Suskind, R. (2004). The price of loyalty: George W. Bush, the White House, and the education of Paul O'Neill. New York: Simon \& Schuster. 